\title{
Analysis of Public Opinion on Fake Information during the Covid-19 Pandemic: Literature Review
}

\author{
Nadhira Meizahra ${ }^{1}$, Tia Ivanka Wardani², Moses Glorino Rumambo Pandin ${ }^{3}$ \\ ${ }^{1}$ Japanese Studies, Faculty of Humanities, Airlangga University \\ ${ }^{2}$ English Literature, Faculty of Humanities, Airlangga University \\ ${ }^{3}$ Lecture at Faculty of Humanities, Airlangga University
}

Corresponding Authors: Tia Ivanka Wardani, Student at Faculty of Humanities, Universitas Airlangga, Email: tia.ivanka.wardani-2020@fib.unair.ac.id

\begin{abstract}
Along with the increasing number of Covid-19 cases, the development of false news or misinformation about Covid-19 -19 is getting bigger. This article aims to analyze public opinion about the various hoaxes that were widely spread in Indonesia during the pandemic. The method used is a mixture, namely literature review, in the form of searching for related journals regarding the distribution of hoaxes during the pandemic and conducting online surveys via google form. The research conducted indicates that during the pandemic there was a rapid spreadness of fake news, it is proven with more than $45 \%$ of the participants who were often heard hoax news about Covid-19 on online media. From this evidence it also can be discovered that hoax news can affect a person's belief on the Covid-19 virus.
\end{abstract}

Keywords: Covid-19; fake news; health protocols; belief

\section{INTRODUCTION}

The first Covid-19 virus was officially announced on March 11, 2020 (1). As on April 19, 2021 through the official worldometer website (2), Covid-19 cases reached $142,102,302$ worldwide and more than 3,035,109 have died. Along with the increasing number of the Covid-19 cases, the spreadness of fake news or misinformation about the virus is getting bigger (3). This is caused by a crisis situation occupied with uncertainty and fear, and it speeds up the excessive information about a problem on social media (4).

According to the official website of "Digital 2021: Global Overview Report"(5), it is known that now, the active internet users in Indonesia have reached 170 million out of a total of 274.9 million population in Indonesia. This large number has figured out the reason why it was very easy for hoax to spread out rapidly. The valuable uses of technology that supports easy-ways to access the information, were abused to produce inaccurate and unreliable news (6).

As a new disease, there is not much information about this virus to obtain in public. This has led to the appearance of social stigma against certain groups that are considered to have a relationship with this virus, such as a bad judgment to patients and their families, nurses and health workers or those who are not sick but have symptoms similar to COVID-19. If this stigma continues to be maintained, this can leds people to 
hide their sickness and are reluctant to seek medical assistance immediately to prevent themselves from discrimination (7).

In accordance with $\mathrm{CNN}$ Indonesia (9), there is a false information related to Covid-19 vaccine, that a barcode in the vaccine is used as a tracking device to track the body of the person who had been injected, but the fact is that the barcode on the package were used to track the distribution of the vaccine. This is evidence that along with a large amount of fake information that widely spread on social media, it has been affecting the public opinion on the prevention regulations. As a result, people no longer trust the recommendations of experts on the effort to reduce the infection rate of the Covid-19 virus (8).

This article aims to analyze public opinion about various hoax news that were widely spread in Indonesia during the Covid-19 pandemic. By combining several keywords this article raises research questions (1) How often do respondents hear hoax news about the corona virus on social media? and (2) Has the spread of fake news affected the implementation of health protocols during the pandemic?.

\section{METHODS}

This research used a mix-methods namely literature reviews, in the form of searching for related journals regarding the distribution of hoaxes during the Covid-19 pandemic and conducting an online survey via google form.

Primary qualitative data taken were 12 journal articles from Pubmed, ScienceDirect and Google Scholar. And secondary qualitative data is taken from 3 official news pages on the internet regarding the spread of Covid-19 in the world and Indonesia. The data collection process is (1) determining research problems, (2) searching for articles related to research problems, (3) reading journal articles that have been collected, (4) citing related information from the articles obtained.

Quantitative primary data was also added by conducting a survey via Google Form from 51 participants from the internet. The data collection process is (1) determining the questions to be asked, (2) determining the minimum target, (3) creating a google form, (4) distributing google form surveys through social media, (5) combining data obtained from survey results, and (6) presents the data in the article.

\section{RESULTS}

Based on data obtained from a survey via Google form, with 51 students as participants who responded to the following results.

Have you ever heard hoax news about Covid-19? 90.2\% of participants respond that they have heard hoax news about Covid-19. Based on the survey results, we ask about how often have you heard hoax news on social media?, the results shows that $51 \%$ of 
people ever heard about hoax news, $45.1 \%$ of people answered often heard the hoax news and the rest answered never heard about hoax news.

$78.4 \%$ of the survey results also stated that people thought the person who created the hoax news had a specific reason or purpose, while $21.6 \%$ thought there was no specific reason related to the spread of the news.

Based on the survey results, $94.1 \%$ of participants disagreed that the spread of hoax videos in the midst of a pandemic was not a common thing and 5,9\% they choose maybe. According to the table, it can be seen that $96.1 \%$ of participants agreed that hoax spreaders must be acted decisively according to the Indonesian law. However, the rest of the participants thought it was not necessary and suggested to only inform the creator that the news was false.

Table 1. Collections of the Respondents' Answers

\begin{tabular}{|c|c|c|c|}
\hline Questions & Answers & Percentage & Total Respondents \\
\hline \multirow{2}{*}{$\begin{array}{c}\text { Have you ever heard hoax } \\
\text { news about Covid-19? }\end{array}$} & Yes, I have & $90,2 \%$ & 46 out of 51 \\
\hline & No, I have not & $9,8 \%$ & 5 out of 51 \\
\hline \multirow{3}{*}{$\begin{array}{c}\text { Have you ever heard hoax } \\
\text { news on social media? }\end{array}$} & Yes, I ever & $51 \%$ & 26 out of 51 \\
\hline & Yes, Often & $45.1 \%$ & 23 out of 51 \\
\hline & No, never & $4,9 \%$ & 2 out of 51 \\
\hline \multirow{2}{*}{$\begin{array}{l}\text { Do you think there is a } \\
\text { reason or specific purpose } \\
\text { for the perpetrator to } \\
\text { spread the hoax? }\end{array}$} & Yes, I think so & $78.4 \%$ & 40 out of 51 \\
\hline & $\begin{array}{l}\text { No, I don’t } \\
\text { think so }\end{array}$ & $21.6 \%$ & 11 out of 51 \\
\hline \multirow{3}{*}{$\begin{array}{l}\text { Do you think the spread of } \\
\text { hoax videos is a common } \\
\text { thing during a pandemic? }\end{array}$} & Yes, I do & $0 \%$ & 0 out of 51 \\
\hline & No, I don’t & $94,1 \%$ & 48 out of 51 \\
\hline & Maybe & $5,9 \%$ & 3 out of 51 \\
\hline \multirow{2}{*}{$\begin{array}{l}\text { Do you agree that the } \\
\text { perpetrators who spread } \\
\text { hoax news need to be dealt } \\
\text { with firmly? }\end{array}$} & Yes, I agree & $96.1 \%$ & 49 out of 51 \\
\hline & $\begin{array}{l}\text { No, I don't } \\
\text { agree }\end{array}$ & $3,9 \%$ & 2 out of 51 \\
\hline $\begin{array}{l}\text { If you don't agree, in your } \\
\text { opinion, how to deal with } \\
\text { the perpetrators/hoaxers? }\end{array}$ & $\begin{array}{c}\text { It was not } \\
\text { necessary and } \\
\text { there are still a } \\
\text { lot of issues to } \\
\text { be solved by } \\
\text { the } \\
\text { government. }\end{array}$ & $\begin{array}{l}\text { One of the } \\
\text { respondent } \\
\mathrm{S} \text { with } \\
\text { initials FA }\end{array}$ & 1 out of 51 \\
\hline
\end{tabular}




\begin{tabular}{|c|c|c|}
\hline $\begin{array}{l}\text { I suggested to } \\
\text { only inform the } \\
\text { creator that the } \\
\text { news was false. }\end{array}$ & - & 1 out of 51 \\
\hline
\end{tabular}

\section{DISCUSSION}

Fake news can be called as false information, including myths, rumors, conspiracy theories, hoaxes, as well as deceptive content that is widely spread on social media platforms (10). Along with the rapid expansion of the digital era, social media now has become an evolving place for the dissemination of fake or untrue information. During this pandemic, fake news became a global phenomenon (4), prompting the expansion of fake information about Covid-19 virus. Consequently, many people followed fake precautions that were shared online and it makes a bad impact on public health (11).

The situation worsens when the public doesn't trust the government, research institutions and the pharmaceutical industry regulations. This uncertainty increases the number of people who will reject the Covid-19 vaccine as a prevention movement. Therefore, doctors and health authorities must design appropriate interventions to address this problem and as well as the government who also needs to reassure clear, consistent and transparent information to the public. So that it would retrieve the trust of the general public in this pandemic crisis (12)(13). The survey results indicated that during the pandemic, fake news has spread rapidly. It can be seen by the large number of participants who often heard about hoax news.

Based on the literature review, it was also found that hoax news can affect a person's belief in the COVID-19 virus. This is supported by the results of research (14) that those who believe in conspiracy or hoax about the COVID-19 virus are less anticipated to follow the COVID-19 health protocol guidelines.

However, on the other results, the public also agrees that the development of hoax news is something that is immoderate. This result is related to previous research (15) shows that there is a difference between the creation and distribution of fake content on online media platforms. The implication is that sharing fake news may be unintentional, so that people re-share the fake content with the purpose to help others (11) and do not know that the news was false. Further research is suggested to be able to explore the public response regarding the distribution of fake news and its impact on the implementation of health protocols during the Covid-19 pandemic deeply. 


\section{CONCLUSION}

Fake news or hoaxes have become a global phenomenon during this pandemic. The increasing number of fake news about this virus that widely spread on social media can damage human health because many people are affected by various spread issues and no longer follow the rules of health workers or regulations from the government. If this continues, this will worsen the spread of this mutated virus. Therefore, the government together with health authorities must focus on reassuring transparent and accurate information during this time to retrieve the trust of the community in this pandemic crisis.

\section{REFERENCES}

1. Karić T, Međedović J. Covid-19 conspiracy beliefs and containment-related behavior: The role of political trust. Individual Press Dif. 2021; 175 (October 2020).

2. WORLDOMETER [Internet]. 20 April 2021. 2021 [cited 2021 Apr 20]. Available from: https://www.worldometers.info/coronavirus/

3. Shahi GK, Dirkson A, Majchrzak TA. An exploratory study of COVID-19 misinformation on Twitter. Online Soc Networks Media [Internet]. 2021; 22 (September 2020): 100104. Available from: https://doi.org/10.1016/j.osnem.2020.100104

4. Ceron W, de-Lima-Santos MF, Quiles MG. Fake news agenda in the era of COVID-19: Identifying trends through fact-checking content. Online Soc Networks Media [Internet]. 2021; 21 (December 2020): 100116. Available from: https://doi.org/10.1016/j.osnem.2020.100116

5. Kemp S. DIGITAL 2021: GLOBAL OVERVIEW REPORT [Internet]. 27 JANUARY 2021. 2021 [cited 2021 Apr 20]. Available from: https://datareportal.com/reports/digital-2021-global-overview-report

6. Lubis F. Analysis of Hoax Perpetrators Control Policy and Speech Analysis of Hoax and Players Control Policies Hate Speech. 2020; 9 (1): 79-86.

7. Dai NF. Community Stigma Against the Covid-19 Pandemic. East Indonesia Univ Nursing Study Program. 2020; 66-73.

8. Imhoff R, Lamberty P. A Bioweapon or a Hoax? The Link Between Distinct Conspiracy Beliefs About the Coronavirus Disease (COVID-19) Outbreak and Pandemic Behavior. Soc Psychol Personal Sci. 2020; 11 (8): 1110-8.

9. Vaccine Hoaxes Rise, There are Sanctions for Manufacturers and Spreaders [Internet]. 27 JANUARY 20212021. 2021 [cited 2021 Apr 20]. Available from: https://www.cnnindonesia.com/teknologi/20210127145723-192-599081/hoaxvaksin-naik-ada-sanksi-untuk-pembuat-dan-penyebar

10. Apuke OD, Omar B. Fake news and COVID -19: modeling the predictors of fake news sharing among social media users. Telematous Informatics [Internet]. 2021; 56 (March): 101475. Available from: https://doi.org/10.1016/j.tele.2020.101475 
11. Hou Z, Du F, Jiang H, Zhou X, Lin L, Assessment T, et al. Affiliations: 2020;

12. Judge MS. SARS-CoV-2, Covid-19, and the debunking of conspiracy theories. Rev Med Virol. 2021; (December 2020): 1-11.

13. Earnshaw VA, Eaton LA, Kalichman SC, Brousseau NM, Hill EC, Fox AB. COVID-19 conspiracy beliefs, health behaviors, and policy support. Transl Behav Med. 2020; 10 (4): 850-6.

14. Stanley ML, Barr N, Peters K, Seli P. Analytic-thinking predicts hoax beliefs and helping behaviors in response to the COVID-19 pandemic. Think Reason [Internet]. 2020; $0 \quad(0)$ : $\quad 1-14 . \quad$ Available from: https://doi.org/10.1080/13546783.2020.1813806

15. Egelhofer JL, Lecheler S. Fake news as a two-dimensional phenomenon: a framework and research agenda. Ann Int Commun Assoc [Internet]. 2019; 43 (2): 97-116. Available from: https://doi.org/10.1080/23808985.2019.1602782 